\title{
The mechanisms of thrombin formation
}

Citation for published version (APA):

Beguin, S., Devilee, P. P., \& Hemker, H. C. (1989). The mechanisms of thrombin formation. In S. Dawids (Ed.), Polymers: Their Properties and Blood Compatibility (1 ed., pp. 81-104). Kluwer Academic Publishers.

Document status and date:

Published: 01/01/1989

Document Version:

Publisher's PDF, also known as Version of record

\section{Please check the document version of this publication:}

- A submitted manuscript is the version of the article upon submission and before peer-review. There can be important differences between the submitted version and the official published version of record.

People interested in the research are advised to contact the author for the final version of the publication, or visit the DOI to the publisher's website.

- The final author version and the galley proof are versions of the publication after peer review.

- The final published version features the final layout of the paper including the volume, issue and page numbers.

Link to publication

\footnotetext{
General rights rights.

- You may freely distribute the URL identifying the publication in the public portal. please follow below link for the End User Agreement:

www.umlib.nl/taverne-license

Take down policy

If you believe that this document breaches copyright please contact us at:

repository@maastrichtuniversity.nl

providing details and we will investigate your claim.
}

Copyright and moral rights for the publications made accessible in the public portal are retained by the authors and/or other copyright owners and it is a condition of accessing publications that users recognise and abide by the legal requirements associated with these

- Users may download and print one copy of any publication from the public portal for the purpose of private study or research.

- You may not further distribute the material or use it for any profit-making activity or commercial gain

If the publication is distributed under the terms of Article $25 \mathrm{fa}$ of the Dutch Copyright Act, indicated by the "Taverne" license above, 


\section{THE MECHANISMS OF THROMBIN FORMATION}

S. Béguin, P.P. Devilée, H.C. Hemker $+$

Department of Biochemistry, University of Limburg, Biomedical Center, P.0. Box 616, 6200 MD Maastricht, The Netherlands.

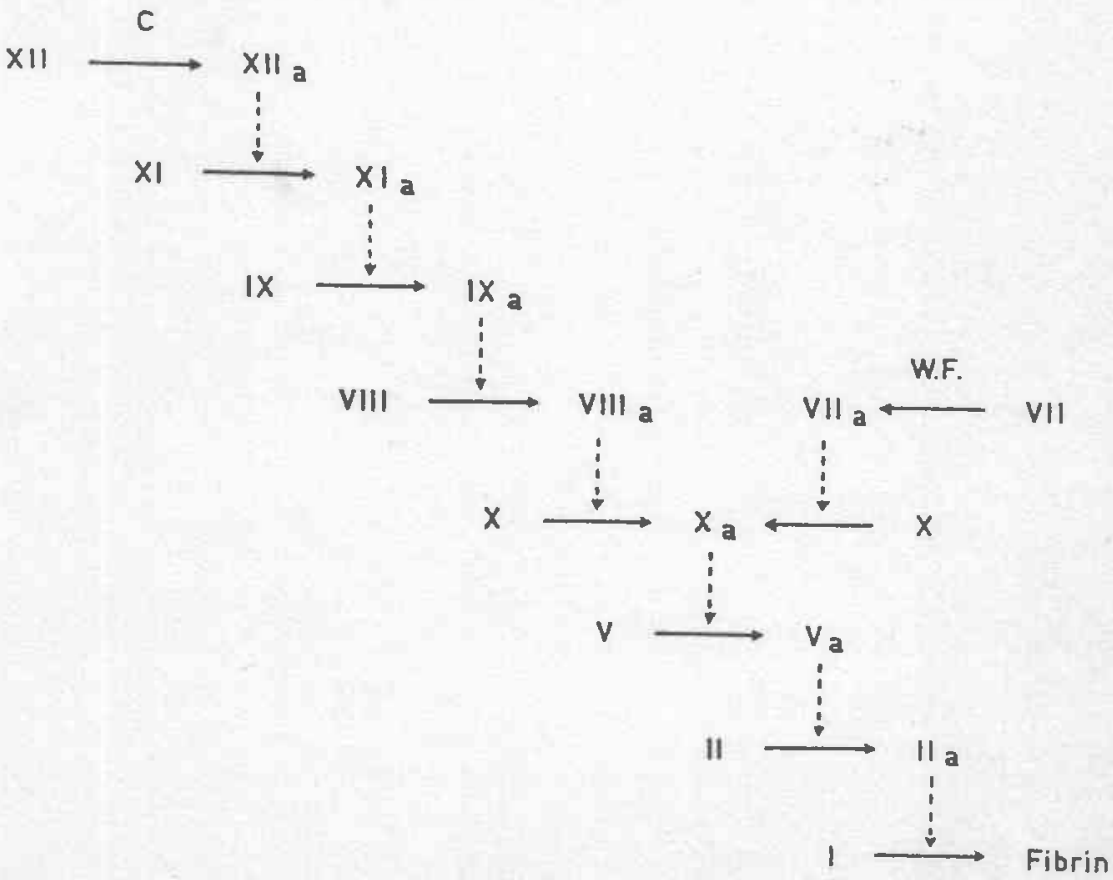

Pig. 1 The classical coagulation cascide (Macfarlane 1969) 
Thrombin is the pivotal enzyme of haemostasis and thrombosis. It catalyzes many important reactions in these processes among which coagulation in the strict sense of the word, i.e. the enzymatic conversion of fibrinogen in fibrin by thrombin. The formation of thrombin in the blood results from a complicated series of chemical and physical interactions; its subsequent inactivation also. In vivo these opposite mechanisms (activation-inactivation) are tuned so precisely that the blood remains fluid in the vessels but any leak is promptly mended. When this equilibrium is disrupted either bleeding or thrombosis will ensue.

Because of the enormous progress in modern coagulation biochemistry, resulting in the isolation and purification of the proteins of coagulation and detailed enzymological studies on their interactions, it is readily possible at this moment to give a plausible scheme of the biochemical reactions which contribute to the formation and to the disappearance of thrombin. Especially in the last ten years, kinetic studies of isolated steps of the coagulation mechanism revealed many details of the biochemical mechanisms involved. There is a consensus on the existence of two pathways that explain the mechanism of the coagulation of blood: the intrinsic pathway operative when coagulaticn is started by contact of blood with glass or other foreign surfaces, and the extrinsic pathway triggered by the addition of tissue thromboplastin. In both cases, calcium is essential. However, these standard schemes of blood coagulation proposed for in vitro situations will not necessarily apply in vivo. Thus some questions from the patho-physiology of blood coagulation remain even today without answer, e.g.: How to explain the importance of the intrinsic pathway in vivo in the obvious absence of foreign surfaces? or: Why do haemophiliacs bleed whereas the proband of Factor XII deficiency, Mr. Hageman had no bleeding problems and died of thrombosis? or: Why is it that heparin hardly influences the thromboplastin time and in the same concentration has a marked influence both on the thrombin 
time and the activated partial thromboplastin time? again: Why do some kinds of thrombopathies show clotting disorders whereas mist do not? and: How to explain the origin of early traces of thrombin necessary to activate Factors $V$ and VIII? The answer to these questions does not readily follow from the classical coagulation schemes. Other interactions between the clotting factors must exist. In the course of the years any accessory reactions, not featuring in the clasical scheres ("cross reactions") have been demonstrated to be possible in vitro but it remains difficult to see which of them are of importance in vivo and which are not.

Already in 1976, Hurlet-Birk Jensen, Josso and Beguin produced evidence for thrombin formation in the very early stage of haemostasis before clotting occurred. This was done by means of the measurement of the activation of factors $V$ and VIII in the blood flowing from $a$ wound in normal and congenitally deficient subjects. This type of experiments requires the presence of patients in the laboratory, because the activation of the factors is not stable and difficult to quantify if the determinations are not carried out immediately. This is one example of the importance of close collaboration between the clinics and the research laboratory for the study of haemostasis and thrombosis. The older literature abounds with more examples but even today, patients like those exibiting abnormal prothrombin (prothrombin Metz, prothrombin Barcelona), abnormal antithrombin III (AT III Alger) or the scott thrombopathy show that the experiments of nature, that can be found by attentive physicians among the patients under their care, are never to be neglected. In general, the (patho)physiology of haemostasis and thrombosis has a wider scope than the study of interactions of isolated coagulation factors. This has to be kept in mind while reading a review on coagulation biochemistry.

The basis of the physiology of the coagulation were established in the second part of XIXth century. After the discovery of thrombin (Buchanan 1836-1845, Schmidt 
1861-1892) the definition of fibrinogen (Virchow 1856; Denis $1859)$ and its isolation by Hamnarsten (1876-1880), the demonstration of the important role cf calcium in coagulation (Arthus and Pages 189u) and finally the discovery of "prothrombin" by Pekelharing in 1895, Morawitz in 1905 proposed the first coherent model of coagulation, which will then be maintained during some forty years. In 1940 seegers purified "prothrombin" (i.e. what is now known to be a mixture of the factors II, VII, IX and $X$ ). This opened the era of modern biochemical coagulatio research. Yet, still in 1947, only two proteins of coagulation were sufficiently defined: fibrinogen and prothrombin. In that year owren published his study on Factor $V$ (proaccelerin). Concomitantly Owren created a methodology which allowed the discovering of ten clotting factors. In 1964, the hypothesis of a "cascade" of enzymatic reactions was advanced by Mac Farlane. This was the trigger for many enzyme mechanistic studies that led to the establishment of a reaction sequence that we will discuss now.

A. THE CLASSICAL COAGULATION MECHANISM.

1. Activation by 1 imited proteolysis.

The mechanism of activation by 1 imited proteolysis is central in the blood coagulation reaction sequence. studies on digestive proteolytic enzymes ((chymo)trypsin, pepsin etc) and their zymogens have made proenzyme $\longrightarrow$ enzyme conversions of proteolytic enzymes one of the main subjects of classical enzymology $(1,2)$. The main chain of tissue thromboplastin induced proteolytic activations in blood is: *

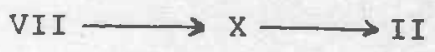

For intrinsic coagulation the main chain of activations is (3):

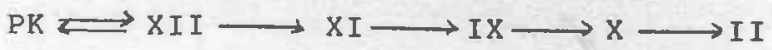


All the non-activated clotting factors participating in these chains are proenzymes of serine proteases, the activated enzymes consequently are serine proteases.

2. Heterogenous biocatalysis.

The proteolytic activations shown above can be obtained when the molecules encounter in free aqueous solution. They are accelerated up to 100.000 fold however by the presence of a phospholipid interface and specific protein cofactors. To illustrate this mechanism we will take the activation of prothrombin as an example. Factor $x_{a}$ is capable to generate thrombin from prothrombin in free solution, but only in a very ineffective mechanism $(4,5,6)$. Hanahan \& Papahadjopoulos $(7)$ were the first to observe that an active prothrombinase exists only in preparations that contain the three components $\mathrm{FX}_{a}$, FV and phospholipid. (The question of factor $V$ activation will be discussed later). Hemker et al (8) showed that the generation of prothrombinase activity can be described as the reversible formation of a complex of $\mathrm{FX}_{\mathbf{a}}$ ' FV and phospholipid. In a series of very elegant experiments Rosing et al (9) later showed that phospholipids diminish the $\mathrm{K}_{\mathrm{m}}$ for prothrombin

* Footnote:

Arrows indicate activation steps, double arrows mean mutual activation. Brackets indicate multienzyme complexes.

PK = Prekallikrein, TF = Tissue Factor, PL = Phospholipids.

Roman numerals indicate the factors. II = prothrombin. 
conversion (a typical change would be from $3000 \mathrm{nM}$ to $30 \mathrm{nM}$ ) whereas Factor $\mathrm{V}_{\mathrm{a}}$ increases the turnover number ( $\mathrm{k}_{\mathrm{cat}}$ ) abou. 1000 fold.

Furthe: investigations (9-16) showed that the change in is caused by the fact that the lipid bound enzyme has higher affinity for the substrate then the free enzyme has The change in $k_{\text {cat }}$ is probably brought about by an alignmen: of the active-site of Factor $x_{a}$ to the vulnerable sites of Factor II caused by their mutual interaction with Factor $V_{a}$.

In 1967 Hemker and Kahn (17) found that the Factor $x$ activating enzyme is a complex of the Factors VIII and IX $_{a}$ and phospholipid, completely comparable to the prothrombinase complex. Later, van Dieijen et al (18) showed that in this complex the kinetic effects of phospholipids (on $\mathrm{K}_{\mathrm{m}}$ ) and Factor VIII (on $k_{c a t}$ ) were similar to those of phospholipid and Factor $v_{a}$ in the prothrombinase complex. Apart from their kinetic effect on $k_{c a t}$, the factors $v_{a}$ and VIII also serve to better bind their respective enzymes ( $\mathrm{Fx}_{a}$ and FIX $\left.{ }_{a}\right)$ to phospholipid $(19,20)$.

The available data, primarily those coming from the laboratory of Nemerson (21) indicate clearly that Factor VII and tissue thromboplastin form a complex that is again comparable to prothrombinase. In this case the protein cofactor and the phospholipid are intimately bound but the mechanistic role of the protein cofactor, like Factor ' $a$ ' seems to be to enhance the efficiency of the enzyme whereas the lipid serves to booster the affinity for the substrate. The most obvious difference with the other complexes resides in the fact that tissue thromboplastin does not arise from an on the spot combination of the protein cofactor and the lipid but is a tight lipoprotein complex, shed as such by wounded cells. We will not enlarge upon the surface reactions and cofactors of contact activation here for reasons that will be discussed later.

We can summarize the reactions of the classical coagulation pathways as follows: 
Bxtrinsic pathway:

(VII, T.F., PL)

$\left(\mathrm{X}, \mathrm{V}_{\mathrm{a}}, \mathrm{PL}\right)$ $\rightarrow I I$

Intrinsic pathway:

PK $\longrightarrow \mathrm{XII}$ $\rightarrow \mathrm{XI} \longrightarrow\left(\mathrm{IX}, \mathrm{VIII}_{\mathrm{a}^{\prime}}\right.$ $\mathrm{PL}) \longrightarrow\left(\mathrm{X}, \mathrm{V}_{\mathrm{a}^{\prime}}\right.$ PL $\longrightarrow$ I I

\section{Limitation of thrombin formation}

An overvies of the coagulation reactions is not complete if no account is given of the way in which thrombin formation is limited. Apart from the trivial possibility of substrate exhaustion, more often then not silently assumed to be the clotting delimiter in the older literature, there are two main mechanisms to be considered: scavening of coagulation proteases by antithrombin III, $\alpha_{2}$ Macroglobul in and other antiproteases $\left(\alpha_{1}\right.$ antitrypsin) (see ref. 22 for a review) and breakdown of the protein cofactors ( $\mathrm{FV}_{\mathrm{a}}$ and FVIII $)$ by activated protein C (together with protein S) $(23,24)$. Protein C and protein $S$ are $v$ itamin $K$ dependent proteins circulating in the plasma, $(25,26)$. Protein $C$ is activated by thrombin adsorbed onto thrombomodulin (27). Because thrombomodulin occurs at the surface of intact endothelium this mechanism may help to limit thrombin formation to wounded areas.

Among the anti-proteases, AT III is extremely important because of the fact that its activity can be enhanced by heparins (28-30) which makes it the lever on which this important family of antithrombotic drugs acts. 
B. FEEDBACK REACTIONS

1. Activation of factors $v$ and $V I I$ by thrombin.

It has been shown that both Factor VIII and Factor $V$ have to be activated before they can play their role as a protein cofactor, and that thromin is the enzyme that brings about these activations (31-34). Thrombin-activated Factor $V\left(F \cdot V_{a}\right)$ in a purified state, when kept under the right conditions is relatively stable. The active state of factor VIII always seems to be a transient phenomenon, ending in inactivation. The activation of Factor $V$ has been described in terms of protein chemistry. The single chain molecule of Factor $V$ is cleaved in three places by thrombin and two of the four resulting fragments recombine under the influence of $\mathrm{Ca}^{++}$to form Factor $\mathrm{V}_{a}$. The mode of interaction between Factor VIII and thrombin probably is a similar process (35). It has been described that in a human system factor $\mathrm{X}_{\mathrm{a}}$ can activate Factor VIII (36).

At this moment it is established beyond any reasonable doubt that activation of the Factors $V$ and VIII is obligatory for their taking part in the coagulation mechanism. This does not mean however that we know wether these reactions are physiologically important. To be more exact: it is essential to know wether these activations play a rate limiting role under physiological condicions and what the physiological activator is. From the work of Hurlet et al (37) it may be concluded that the activatior. of $V$ and VIII does occur in vivo" in the time course of normal haemostasis. An aberrant prothrombin that possibly yields a thrombin incapable of activating Factor $v$, prothrombin Metz $(38,39)$ causes a mild bleeding disorder. Recent results obtained by the authors and to be published elsewhere indicate the feedbacks activation of factor VIII is rate limiting in the intrinsic pathways, wheras that of factor $V$ is not. 
2. Activation of platelets by thrombin.

Thrombin is the most potent physiological platelet activator known $(40)$, a concentration of 0.1 to $1.0 \mathrm{nM}$ will suffice to trigger a half maximal release reaction. All other activators of human platelets need concentrations that are one or more orders of magnitude higher if they are to cause the same response.

Among the proteins released by platelets are Factor $\mathrm{V}$ and heparin neutralizing proteins (platelet factor 4). The amount of Factor $V$ sequestered in the platelets is roughly 208 of the amount present in the plasma (41). Thrombin, that causes the release reaction will also activate the released Factor $V$. It has been shown that this activation rather then the release reaction itself is the rate limiting factor for the generation of Factor $\checkmark$ activity from triggered platelets (42). The concentration of Factor $V$ in platelet poor plasma is about 25 $\mathrm{nM}$ whereas that of its partner, Factor $\mathrm{X}$ is around 200 nM. This may lead one to think that the contribution of platelet Factor $V$ may be important in vivo. The aggregation of platelets at sites where the hemostatic mechanism is active will cause a further increase in the ratio of platelet-Factor $V$ to plasma-factor $V$. Still patients with a storage pool deficiency that are unable to release Factor $V$ from their platelets do not have an important hemorrhagic diathesis (43). It seems that only patients lacking Factor $\mathrm{V}$ in both platelets and plasma do show a hemorrhagic syndrome (44). This may be explained by the generally recognized fact that the normal level of any clotting factor represents a large functional excess. As a rule the level of any clotting factor must drop significantly below 10 s before a decrease of the clotting function becomes apparent.

A second procoagulant function of platelets induced by thrombin together with collagen is the platelet "flip-flop" reaction discovered by Bevers et al. (45). 
This reaction consists of a transbilayer movement of the procoagulant, negatively charged phospholipids (primarily phosphatidyl serine) that as a rule are to be found almost exclusively at the inner face of the cell membrane. In the presence of collagen and thrombin, platelets produce these procoagulant phospholipids at the outside of the cell without the cell being disrupted. The precise molecular mechanism of this reaction is not yet clear. Anyhow, platelets thus activated, offer large amounts of binding sites for the Factors IX $_{a}, V I_{a}, x_{a}$ and $V_{a}$ at their outer surface so that prothrombinase and the Factor $X$ activating enzyme can readily form there. One patient (Mrs. Scott, USA) has been described in which this mechanism is defective, she suffers from a mild haemorrhagic diathesis consequently known as scotts syndrome.

It has been reported that collagen-activated platelets can start coagulation via a Factor XI dependent mechanism and that ADP activation of platelets triggers coagulation via Factor XII (47). These findings remain to be confirmed. The recint observation that platelets release a potent inhibitor of Factor $X I$, so that Factor IX activation by Factor XI a hardly proceeds in the presence of activated platelets (48) makes one doubt the importance of contact activation for in vivo thrombin generation.

\section{The Josso loop.}

In the classical view, contact factors and antihemophilic factors form the intrinsic pathway of thrombin formation and the importance of the role of the contact factors is derived from the recognized importance of the antihemophilic factors. The activating action of Factor VII on Factor IX invalidates this argument. The first indications that the action of the antihemophilic factors (FVIII and FIX) is not confined to the coagulation pathway started by the contact factors were obtained by 
Biggs and Nossel (49). Josso (50) was the first to postulate that Factor VII can activate Factor IX so that the antihemophilic factors play a role in thromboplastin triggered coagulaticn. This means that Factor $X$ can be activated either di ctly by Factor VII and tissue thromboplastin or indirectly by Factor $I_{\mathrm{a}}$ (together with Factor VIII ) that, in its turn has been activated by Factor VII (see fig. 1). It is easy to see that the function of this pathway will anyhow be dependent upon the amount of thromboplastin available. The contribution of the direct, one-step action of Factor VII on Factor $x_{a}$ formation will be constant in time and roughly proportional to the concentration of thromboplastin. The contribution via the pathway VII $\longrightarrow \mathrm{IX} \longrightarrow \mathrm{X}$ will be small in the beginning of the reaction but will increase proportionally with time as the Factor $X$ activating enzyme (i.e. Factor $I_{a}$ ) builds up. Therefore the reinforcement loop constituted by the antihemophilic factors - which we proposed to call the Josso loop after its discoverer (50) - will gain in importance when clotting is started by smaller amounts of thromboplastin. The early observations on the interconnections between the extrinsic and the intrinsic pathway did not get the attention they deserved until Østerud and Rappaport drew attention to the fact that the Factor VII- thromboplastin complex is capable of activating Factor IX in a partially purified system (51). Later Zur and Nemerson (52) Jesty and Silverberg (53) and Marlar and Griffin (54) established this pathway without any reasonable doubt. The physiological importance of the Josso loop is difficult to ascertain because of the thromboplastin dependent and hence time dependent effect discussed above. It is tempting to use the Josso-loop mechanism as a tencative explanation for the clinical observation that hemophiliacs tend to bleed in thromboplastin poor organs such as joints, but this can hardly be accepted as a proof of its importance. Jesty and Silverberg (53) 
calculate that the activation of Factor $X$ by Factor VII is 6 to 7 times faster than the activation of Factor $x$. Zur and Nemerson (52) find a ratio of 10 of the theoretical maximal velocities but argue that the actual ratio will be completely dependent upon the thromboplastin concentration. Van de Besselaar et al. (55) conclude from observations in deficient human plasmas that the Josso loop may be of no importance in human plasma. Clearly the issue is not settled as yet. Recent unpubliserd work from the present authors demonstrates that at low concentations of tissue thromboplastin the Josso loop ccatributes significantly to thrombin generation in whole plasma.

Kalousek et al. (56) have reported that Factor $x$ is able to activate Factor IX. This would constitute a mutual activation interaction that could enhance Factor $x$ activation even without activation of Factor IX by pactor VII. Their experiments have been carried out in purified systems that did not contain protein cofactors (F.V anf F. VIII). Any indication as to the physiological significance of this interaction is lacking at this moment.

\section{Activation of Factor VII.}

The current view on the starting mechanism of coagulation is based on the observation that the proenzyme Factor VII has a non-neglectible enzymatic activity $(57,58)$. Once it adsorbes onto tissue thromboplastin, the activity of Factor VII is enhanced so as to become sufficiently important to start the clotting process. It has been observed however that there exists a more active form of

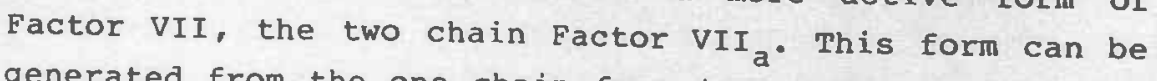
generated from the one chain form in a number of different ways. Altman and Hemker (59) showed, as early as 1967, that the contact activation mechanism can enhance Factor VII activity in vitro. The cold activation of Factor VII, involving kallikrein and different other 
proteins has been well established. It has also been described that Factor VII can be activated by Factor IX and by Factor $x_{a}(60,61)$. A very interesting suggestion is made by silverberg and Jesty (62), when they claim that a complex of Factor VII, tissue thromboplastin and Factor $x_{a}$ in the proteolytically active species.

If anywhere, then it is at the level of the activation of Factor VII that every conceivable reciprocal interaction of clotting factors has been described whereas any indication of their physiological importance is lacking. It is evident that all biochemical observations do not necessarily represent reactions that play a role in (patho) physiology. This being said, it must also be mentioned that often conclusions are drawn too quickly from clinical observations. Tradition has it that the scarce observations of a Factor VII deficiency or of any other rare clotting factor deficiency provoke speculations as to the physiological importance of a deficiency, of that specific factor. Now some observe a low Factor VII level ( $\langle 5 \%$ ) without clinical symptoms whereas others find these patients severely handicapped. The same holds for Factor XI deficiencies and others. In trying to interprete these data one should be aware of the following:

a) Any really important bleeding syndrome will lead to death either before or shortly after birth. Only the relatively mild syndromes survive. We remind of the analogy in thrombophilia: AT III and protein C deficiencies are very rarely seen in the homozygous states, probably because complete deficiencies are lethal to the foetus.

b) Any deficiency that does not lead to a clinically important syndrome will more often then not go unnoticed. It must be kept in mind that the physiological levels of clotting factors as a rule represent a large excess of that factor so that a decrease to as low as 108 of the normal level will not cause any overt disease. The number 
of deficiencies that are recognized not to cause-problems will therefore depend on chance findings and hence be uncier-estimated. This is illustrated by the fact that these disorders tend to cluster around laboratories that specialize in research on the blood coagulation and that are backed up by competent clinicians. We thus see that neither the really important deficiencies nor thos: without any clinical consequences will be recognized in routine necical practice. Therefore it is very hard - if not impossible - to draw conclusions on the mechanism of the blood coagulation process from the correlation between observed clinical symptoms and the accompanying clotting factor deficiencies.

\section{INHIBITORY FEEDBACK REACTIONS}

One may think of several crosslinks between the reactions that inhibit the clotting process and those that enhance thrombin formation.

The thror in feedback reactions play an important role here. As we have discussed before, thrombin will enhance its own formation by activating the factors $V$ and VIII as well as platelets. Any inhibition of thrombin formation and any reaction that inactivates throvir. therefore will interfere with this positive feedback. The interesting question remains in howfar antithrombin III inhibits thrombin formation because it modulates the extend of activation of Factor $V$ or Factor VIII etc. We recently showed that this mechanism is operative in the intrinsic system (unpublished). Because heparin acts via antithrombin III, this means that heparin influences factor VIII dependent coagulation pathways indirectly by inhibiting the feedback activation of factor VIII. Pentosan polysulphate, a heparinlike drug, acts by direct inhibition of factor VIII activation (Wagenvoord et al.. unpublished). Also diminution of the available amount of thrombin will cause a decreased rate of activation of 
protein $C$ and therefore prolong the mean lifetime of the prothrombin and $F$ tor $X$ activating complexes. Again no quantitative dat sre available that allow an estimate of the importarce of this conceivable pathway.

In the second place one has to reckon with competition for clotting proteases between procoagulant complexes and protease scavencers. Here more data are available. It has been observed for instance $(63,64)$ that antithrombin III will attack Factor $x_{a}$ less readily in the presence of phospholipids then in free solution and even less if both phospholipids and Factor $V_{(a)}$ are present. In vivo this protection seems even to be complete (unpublished results). What holds for Factor $x_{a}$ and antithrombin III, in principle holds for all surface bound proteases and all antiproteases. Lipid binding of Factor IX protects this enzyme too from antithrombin III-heparin action.

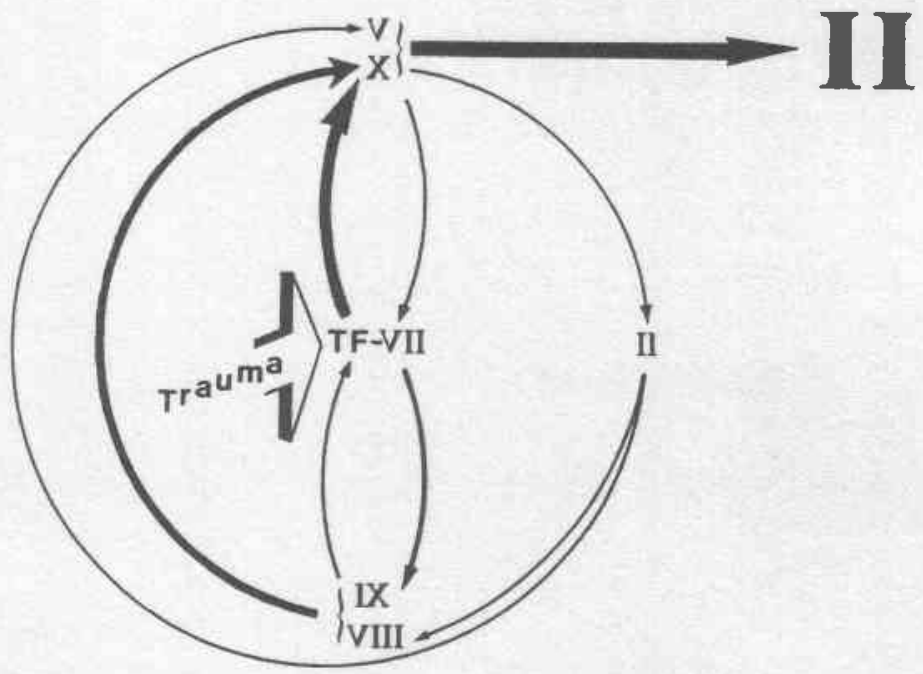

Fig. 1 A coagulation scheme for 1988
The thickness of the lines indicates roughly the rate of the reactions. 
TABLE I

CONCENTRATIONS OF SOME PLASMA PROTEINS

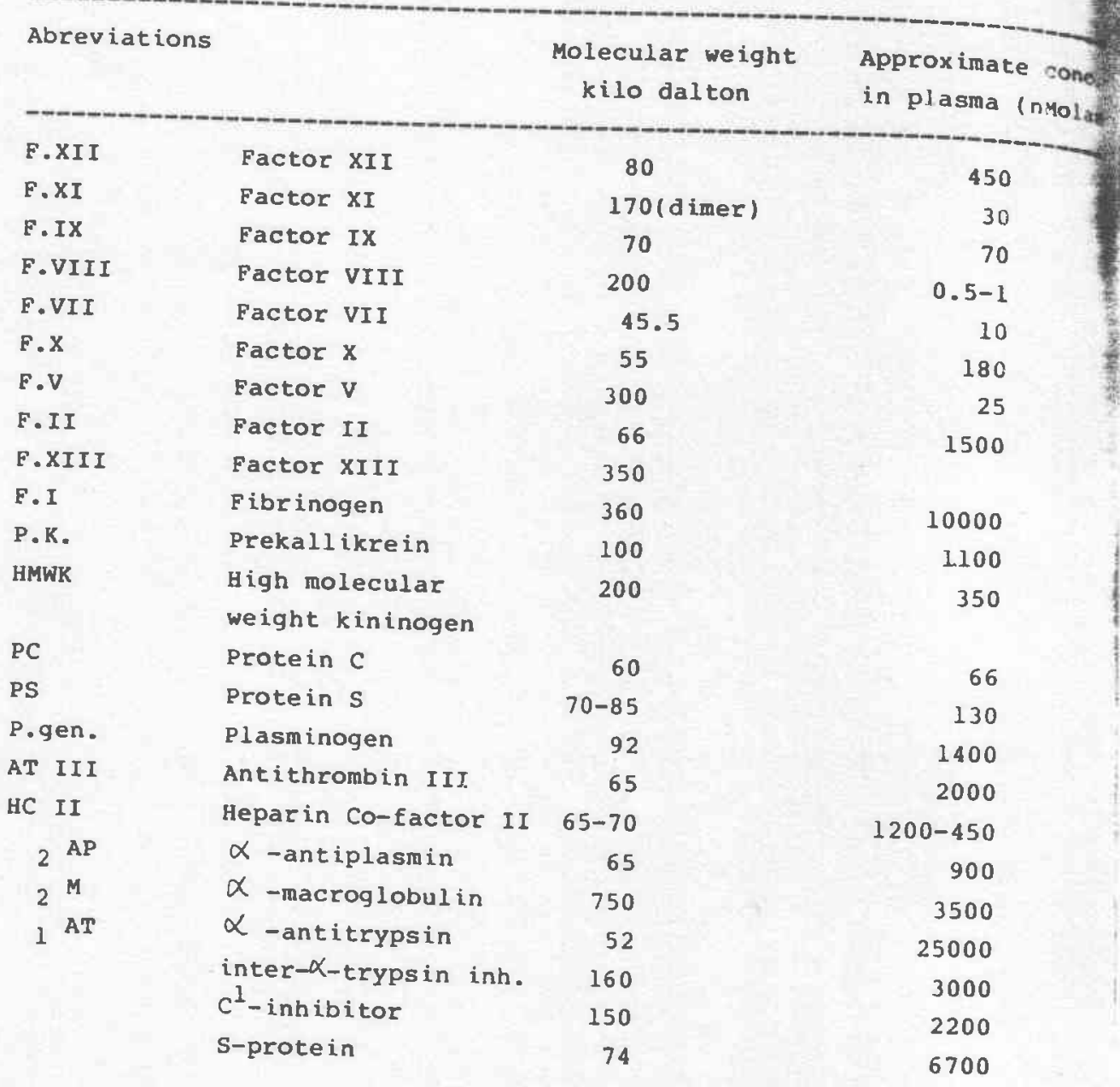


Table II

Thrombin concentrations

$1 \mathrm{~N} / \mathrm{H}$ unit $=0.324 \pm 0.073 \mathrm{ug}$

$1 \mathrm{~N} / \mathrm{H}$ unit $=8.85 \pm 2.01$ pMole

$1 \mathrm{U} / \mathrm{ml} \approx 10 \mathrm{pMole} / \mathrm{ml} \approx 10 \mathrm{nMolar}$

1 IOWA unit $=0.83 \mathrm{~N} / \mathrm{H}$ unfts

1 WHO unit $=0.56 \mathrm{~N} / \mathrm{H}$ unfts

Table III

\section{Heparin concentrations}

1 Unit $\cong 5.5$ ug

1 ug $\approx 0.18$ unit

M.W. $\approx 15.000$

Unit/ml $\approx 400 \mathrm{nMble} / \mathrm{L}$

The values differ from batch to batch

The molecular weight is a rough estimate of the mean molecular weight. 
1. Boyer, P. (ed.): The enzymes, Vol. III. Hydrolysis. Peptide Bonds Academic press, New York, 1970

2. Neurath, .: Structure and function of proteolytic enzymes. : editef by M. Sela, 28-79, "New perspectives in Biology", 28-79, Elsevier, New York.

3. Griffin, J.H., Cochrane, C.G.: Recent advances in the understanding of contact activation reactions. Seminars in Thrombos s and Hemostasis, vol. V 254-273, 1979

4. Esmon, C.T., Jackson, C.M.: The conversion of prothrombin. III: The Factor $x_{a}$, catalyzed activation of prothrombin. J. Biol. Chem. 249,7782-7790, 1974

5. J Jbin, F., Esnouf, M.P.: Studies on the formation of the prothrombinconverting complex. Biochem. J., 102 ,
$666-674,1967$

6. Esmon, C.T., Owen, W.G., Jackson, C.M.: A plausible monanism for prothrombin activation by Factor $x_{a}$. Ijctor ' $a$ ' phospholipid, and calcium ions. J. Biol. Chem., 249, 8045-8047, 1974

7. Papahadjopoulos, L.P., Hanahan, D.J.: Observations on the interaction of phospholipids and certain clotting farcors in prothrombin activator formation. Biochim. Biophys. Acta, 90,436-439, 1964

8. Hemker, H.C., Esnouf, M.P., Hemker, P.W., Swart, A.C.W.. Macfarlane, R.G.: Formation of prothrombin converting

9. Rosing, J., Tans, G., Govers-Riemslag, J.W.P., Zwaal, R.F.A., Hemker, H.C. The role of phospholipids and Factor $\mathrm{V}_{\mathrm{a}}$ in the prothrombinase complex. J. Biol. Chem. $255,274--83,1980$

10. Nesheim, M.E., Eid, S., Mann, K.G.: Assembly of the prothrombinase complex in the absence of prothrombin. J. Biol. Chem. 256, 9874-9882, 1981

11. Van Rijn, J.L.M.L., Govers-Riemslag, J.W.P., Zwaal, R.F.A. Rosing, J.: Kinetic studies of prothrombin activation: Effect of factor $\mathrm{V}_{\mathrm{a}}$, phospholipids on the 
formation of the enzyme-substrate complex. Biochem. 23, 4557-4564, 1984

12. Nelsestuen, G.L.. Kisiel, W., Di Scipio, R.G.: Interaction of $v i t a m i n ~ K$ dependent proteins with membranes. Biochem. 17, 2134-2138, 1978

13. Nesheim, M.E., Mann, K.G.: The kinetics and cofactor dependence of the two cleavages involved in prothrombin activation. J. Biol. Chem., 258, 5386-5391, 1983

14. Nesheim, M.E., Tasiell, J.B., Mann, K.G.: The contribution of bovine Factor $V$ and Factor $V_{a}$ to the activity of prothrombinase. J. Biol. Chem. 254, $10952-10962,1979$

15. Rosing, J., Tans, G., Govers-Riemslag, J.W.P., Zwaal, R.F.A., Hemker, H.C.: The roit of phospholipids and Factor $\mathrm{V}_{\mathrm{a}}$ in the mechanism of prothrombin activation. Thromb. Haemostas. 42, 177 (abstract), 1979

16. Tans, G., Rosing, J. van Dieijen, G. Henker, H.C.: Conjectures on the mode of action of Factor $V$ and VIII. In: The regulation of coagulation, edited by K.G. Mann and E. Taylor, 173-185, Elsevier North Holland, New York, Amsterdam

17. Hemker, H.C., Kahn, M.J.P.: Reaction sequence of blood coagulation. Nature, 215, 1201-1202, 1967

18. Van Dieijen, G., Tans, G., Rosing, J., Hemker, H.C.: The role of phospholipid and Factor VIII in the activation of bovine Factor $\mathrm{X}$.

J. Biol. Chem. 256, 3433-3442, 1981

19. Lindhout, T., Govers-Riemslag, J.W.P., v.d. Waart, P., Hemker, H.C. Rosing, J.: Factor V $\mathrm{a}^{-F a c t o r} \mathrm{X}_{\mathrm{a}}$ interaction. Effects of phospholipid vesicles of varying composition. Biochem, 21, 5494-5502, 1982

20. Van Dieijen, G., van Rijn, J.L.M.L., Govers-Riemslag, J.W.P., Hemker, H.C., Rosing, J.: Assembly of the intrinsic Factor $X$ activating complex; interactions between Factor IX $_{a}$, Factor VIII ${ }_{a}$ and phospholipid. Thromb. Haemostas. 53, 396-400, 1985 
21. Silverberg, S.A., Nemerson, Y., Zur, M., Ostapchuk, P.: Kinetics of the activation of bovine coagulation Factor $X$ by components of the extrinsic pathway. Kinetic behavior of two-chain Factor VII in the presence and absence of tissue factor. J. Biol. Chem., 252 , $8481-8488,1977$

22. Travis., J., Salvesen, G.S.: Human plasma proteinase inhibitors. Ann. Rev. of Biochem. 52, 655-709, 1984

23. Marlar, R.A., Kleiss, A.J., Griffin, J.H.: Human proteir $C$ inactivation of Factor $V$ and VIII in plasma by activated molecule. Ann. N.Y. Acad. Sci., 370, 303-310, 1981

24. Suzuki, K., Stenflo, J., Dahlbäck, B., Teodorsson, B.: Inactivation of human coagulation Factor $V$ by activated protein C. J. Biol. Chem., 258, 1914-1920, 1983

25. Stenflo, J.: A new vitamin K-dependent protein. Purification from bovine plasma and preliminary characterization. J. Biol. Chem. 251, 355-363, 1976

26. Stenflo, J., Junsson, M.: Protein S. A new vitamin K-dependent protein from bovine plasma. Febs. Lett. 101, $377-381,1979$

27. Esmon, C.T., Owen, W.G.: Identification of an endothelial cell cofactor for thrombin-catalyzed activation of protein C. Proc. Nat1. Acad. Sci. USA. 78, 2249-2252, 1981

28. Abildgaard, U.: Highly purified antithrombin III with heparin cofactor activity prepared by disc electrophoresis. Scand. J. Clin. Lab. Invest. 21, 89-91, 1968

29. Biggs, R., Denson, K.W.E., Akman. N., Borrett, R., Hadden, M.: Antithrombin III, Antifactor $x_{a}$, and heparin. Brit. J. Haemat. 19, 283-305, 1970

30. Rosenberg, R.D., Damus, P.S.: The purification and mechanism of action of human anti-thrombin-heparin cofactor. J. Biol. Chem. 248,6490-6505, 1973

31. Newcomb, T.F., Hoshida, M.: Factor $V$ and thrombin. Scand. J. Clin. Lab. Invest. 17 suppl. 84, 61-69, 1965 
2. Bergsagel, E.E., Nockolds, E.R.: The activation of proaccelerin. Brit. J. Haemat. 11, 395-410, 1965

3. Biggs, R., MacFarlane, R.G., Denson, K.W.E., Ash, B.J.: Thrombin and the interaction of Factors VIII and IX. Brit. J. Haemat. 11, 276-295, 1965

44. Suzuki, K., Dahlbäck, B., Stenflo, J.: Thrombin catalyzed activation of human coagulation Factor $V$. J. Biol. Chem. 257, 6556-6564, 1982

35. Vehar, G.A., Davie, E.W.: Preparation and properties of bovine factor VIII (antihemophilic factor). Biochemistry. 19, 401-410, 1980

36. Mertens, K., Bertina, R.M.: Activation of human coagulation Factor VIII by activated Factor $x$, the common product of the intrinsic and the extrinsic pathway of blood coagulation. Thromb. Haemostas. (Stuttgart) 47, 96-100, 1982

37. Hurlet-Birk Jensen, A., Beguin, S., Josso, F.: Factor V and VIII activation "in vivo" during bleeding. Evidence of thrombin formation at the early stage of hemostasis. Path. Biol. 24, 6-10, 1976

38. Rabiet, M.J., Jandrot-Perrus, M., Boissel, J.P., Elion, J., Josso, F.: Thrombin Metz: Characterization of the dysfunctional thrombin derived from a variant of human prothrombin. Blood, 63, 927-934, 1984

39. Josso, F., Rio, Y., Beguin, S.: A new variant of human prothrombin: prothrombin Metz, demonstration in a family showing double heterozygosity for congenital hypoprothrombinemia and dysprothrombinemia. Haemostasis, 12, $309-316,1982$

40. Zücker, M.B., Nachmias, V.T.: Platelets activation. Arteriosclerosis, 5, 2-18, 1985

41. Tracy, P.B., Eid, L.L., Bowie, E.J.W., Mann, K.G.: Radioimmunoassay of factor $V$ in human plasma and platelets. Blood, 60, 59-63, 1982

42. Baruch, D., Hemker, H.C., Lindhout, T.: Kinetics of thrombin induced release and activation of platelet factor V. Eur. J. Biochem. 154, 213-218, 1986 
43. Weiss, H.J., Witte, L.D., Kaplan, K.L. et al.: Heterogenity in storage pool deficiency studies of granule bound substances in 18 patients including variants deficient in alpha granules platelet factor 4 , thromboglobulin and platelet derived growth factor. Blood, 54, 1296-1319, 1979

44. Tracy, P.B., Giles, A.R., Mann, K.G., Eid, L.L., Hoogendoorn, H., Rivard, G.E.: Factor V (Quebec) a bleeding diathesis associated with a qualitative platelet Factor $V$ deficiency. J. Clin. Invest. 74,
$1221-1228,1984$

45. Bevers, E.M., Comfurius, P., van Rijn, J.L.M.L., Hemker, H.C., Zwaal, R.F.A.: Generation of Prothrombin-converting activity and the exposure of phosphatidylserine at the outer surface of platelets. Eur. J. Biochem. 122,

46. Rosing, J., Bevers, E.M., Comfurius, P., Hemker, H.C., van Dieijen, G., Weiss, H.J., Zwaal, R.F.A.: Impaired Factor $X$ and Prothrombin activation associated with decreased phospholipid exposure in platelets from a patient with a bleeding disorder. Blood, 65, (2),

47. Walsh, P.N., Griffin, J.H.: Contributions of human platelets to the proteolytic activation of blood coagulation Factors XII and XI. Blood, 57, 106-118, 1981

48. Soons, H.: Personal communication.

49. Biggs, R., Nossel, H.L.: Tissue extract and the contact reaction in blood coagulation. Thromb. Diath. Haemorrh. $6,1-14,1961$

50. Josso, F., Prou-Wartelle, O.: mteraction of Tissue Factor and Factor VII at the earliest phase of coagulation. Thromb. Diath. Haemorr. Suppl. 17, 35-44,
1965

51. Østerud, B., Rapaport, S.I. Activation of Factor IX by the reaction product of tissue Factor and Factor VII: Additional pathway for initiating blood coagulation. Proc. Nat1. Acad. Sci, USA, 74, 5260-5264, 1977 
7. Zur, M.. Nemerson, Y.: Kinetics of factor IX activation via the extrinsic pathway. J. Biol. Chem. 255, 5703-5707, 1980

3. Jesty, J., Silverberg, S.A.: Kinetics of the tissue factor-dependent activation of coagulation Factors IX and $X$ in a bovine plasma system. J. Biol. Chem. 254, $12337-12345,1979$

54. Marlar, R.A.. Griffin, J.H.: Alternative pathways of thromboplastin-dependent activation of human factor $\mathrm{X}$ plasma. Annals New York Acad. Sciences. 370, 325-335, 1981

55. Van den Besselaar, A.M.H.P., Ram, I.E., Alderkamp, G.H.J., Bertina, R.M.: The role of factor IX in tissue thromboplastin induced coagulation. Thromb. Haemostas. (Stuttgart) $48,54-58,1982$

56. Kalousek, F., Konigsberg, W., Nemerson, Y.: Activation of factor IX by activated factor X: a 1 ink between the extrinsic and intrinsic coagulation systems. Febs. lett. $50,382-385,1975$

57. Jesty, J. Nemerson, Y.: Purification of Factor VII from bovine plasma. Reaction with tissue factor and activation of Factor X. J. Biol. Chem. 249, 509-515, 1974

58. Nemerson, Y.: Regulation of the initiation of coagulation by Factor VII. Haemostas. 13, 150-155, 1983

59. Altman, R., Hemker, H.C.: Contact activation in the extrinsic blood clotting systems. Thromb., Diathes. Haemorrh. (Stuttgart) 18, 525-531, 1967

60. Nemerson, Y.: Biological control of Factor VII. Thrombos. Haemostas. (Stuttgart) 35, 96-100, 1976

61. Radcliffe, R. Nemerson, Y.: Activation and control of Factor VII by activated Factor $X$ and thrombin. Isolation and characterization of a single chain form of Factor VII. J. Biol. Chem. 250, 388-395, 1975

62. Morrisson-Silverberg, S.A., Jesty, J.: The role of activated Factor $\mathrm{X}$ in the control of bovine coagulation Factor VII. J. Biol. Chem. 256, 1625-1630, 1981 
63. Marciniak, E.: Factor $x_{a}$ inactivation by antithrombin III. Evidence for biological stabilization of Factor $v$. J. Biol. Chem. 256, 1625-1630, 1973

64. Josso, F., Beguin, S.: Changes in the antithrombin III activity at the interface plasma-phospholipids. Thromb. Haemostas. 46, 285 (abstract), 1981 